Trakya Üniversitesi

Eğitim Fakültesi Dergisi

Cilt 8, Sayı 2

Ocak 2018, 410-430

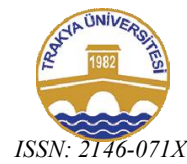

Trakya University

Journal of Education Faculty

Volume 8, Issue 2

January $2018,410-430$

Doi: $10.24315 /$ trkefd. 366686

Geliș Tarihi: 14.11.2016

Yayına Kabul Tarihi: 27.07.2017

\title{
Zamana Bağlı Öğrenme Miktarı: Öğrenmenin Güçlüğü (Kesirlerle Problem Çözme Örneği)
}

\section{Amount of Time-Dependent Learning: Learning Difficulty (The Example of Problem Solving with Fractional)}

\author{
Cenk KEŞAN ${ }^{2}$, Deniz KAYA ${ }^{3}$
}

\begin{abstract}
Öz: $\mathrm{Bu}$ çalışmanın amacı altıncı sınıf öğrencilerinin "kesirlerle işlem yapmayı gerektiren problemleri çözer" kazanımına göre zamana bağlı öğrenme güçlüklerini belirlemektir. Tarama modelinin benimsendiği çalışma altıncı sınıf öğrenim düzeyinde $80 \mathrm{k} 1 z$ ve 68 erkek olmak üzere toplam 148 öğrenci ile yürütülmüştür. Veri toplama aracı olarak açık uçlu 12 sorudan oluşan ölçme aracı kullanılmıştır. Elde edilen bulgular, 148 kişilik öğrenme grubunun tam öğrenme seviyesinden 0.013'lük miktar gerisinde kaldığını göstermektedir. Tam öğrenme miktarı için belirlenen 0.987 alt sınır seviyesine K1 öğrencisi 1.8 , K58 öğrencisi 2.49 ve K148 öğrencisi ise 11.17 ders saati zaman diliminde ulaşmıştır. Tam öğrenme miktarına en yakın değer olan 0.999 öğrenme miktarına öğrenme grubu 6.4, K1 öğrencisi 3.53, K58 öğrencisi 5.81 ve K148 öğrencisi 37.70 ders saati zaman diliminde ulaşmıştır. Bunun yanı sıra elde edilen veriler, zaman ile öğrenme miktarına ait eğrinin altında kalan alan arttığında öğrencilerin daha fazla öğrenme güçlüğü yaşadığını göstermiştir. Çalışma sonucunda, bir öğretim planına sahip tüm eğitim kademelerinde tam öğrenme düzeyine en yakın ders saati sürelerinin belirlenebileceği öneri olarak sunulmuştur.
\end{abstract}

Anahtar sözcükler: Kesirler, matematik eğitimi, öğrenme güçlüğü, zaman

\begin{abstract}
The purpose of this study is a time dependent analysis for learning difficulties of sixth grade students in solving problems that require calculating of swith fractions. The study, adopting the screening model, consisted of a total of 148 students, including 80 female and 68 male students at the sixth grade. Data was collected using an assessment tool consisting of 12 open-ended questions. The findings show that the learning groups of 148 students were behind the value closest to the full learning level by a score of 0.013 . K1 student reached the lower limit of 0.987 specified for the full learning level in a period of 1.8 course hours, K58 student reached this limit in 2.49 course hours and K148 student
\end{abstract}

${ }^{1}$ 5-8 Mayıs 2016 tarihlerinde Çanakkale 18 Mart Üniversitesinde düzenlenen VIII. Uluslararası Eğitim Araştırmaları Kongresinde sözlü bildiri olarak sunulmuștur. ${ }^{2}$ Doç. Dr., Dokuz Eylül Üniversitesi, Buca Eğitim Fakültesi, cenkkesan@gmail.com

光., Milli Eğitim Bakanlığı, denizkaya50@yahoo.com 
reached this limit in 11.17 course hours. The learning amount of 0.999 , which is the closest value to the full learning level, was reached by the learning group in a period of 6.4, K1 student in 3.53, K58 student in 5.81 and the K148 students in 37.70 course hours. Moreover, as there was a decrease in the area under the curve belonging to the learning level-time graphic, there was also a decrement in the number of learning difficulties that the learning group encounters before. As a result of the study, it was recommended that it is possible to determine the closest course periods for the full learning level for each of the gains found in all levels of education and all curricula.

Keywords: Fractions, learning difficulty, mathematics education, time

\section{GíRiş}

Öğrenme sürecini anlamanın önemi ve merakı nedeniyle, alanyazında farklı yaklaşımlarla ele alınmış çok sayıda tanıma rastlamak mümkün olsa da öğrenmenin nasıl şekillendiği, boyutları, miktarı, kullanılabilirliği, nedenleri ve yapısı gibi daha birçok sorunun karşılığı tam olarak anlaşılamamıştır. Öğrenme davranışçı kurama göre, bir organizmanın davranışlarındaki değişme iken bilişsel kuruma göre, öğrencinin ne bildiği ve ona nasıl ulaşabildiği ile ilgilidir (Alkan, Deryakulu ve Şimşek, 1995). Sosyal öğrenme kuramı ise öğrenmeyi sadece bilişsel değil aynı zamanda duyuşsal ve sosyal bir süreç olarak ele almaktadır (Bandura, 1997). Aslında öğrenme dediğimiz kavram "öğrencilerde farklı oranlarda meydana gelen kavramsal değişimin özgün bir sürecidir” (Yağbasan ve Gülçiçek, 2003). Bu sürecin en temel özelliği yeni bilgilerin inşasından ziyade kavramsal değişimin izlerini taşıyor olmasıdır (Scott, Asoko ve Driver, 1991).

Öğrenme süreci; çeşitli psikolojik, biyolojik ve fizyolojik süreçlerin etkisi altında karmaşık bir yapı olmakla beraber öğretim programının içeriği, ders araçgereçleri, kazanımlara ayrılan süre, yöntem çeşitliliğii, eğiticilerin sahip olduğu nitelikler ile öğrenenin sahip olduğu bilgi, birikim ve deneyim olmak üzere daha birçok faktör grubu ile birlikte şekillenmektedir. Alanyazında yer alan çalışmalar incelendiğinde, matematik öğretiminde genellikle öğretim yöntemlerin, bilişsel boyutların ve matematik konuların ele alındığı görülmektedir (Kayhan ve Özgün -Koca, 2004). Bu çalışmaların çoğunluğu belirli konu ve kavramları içermek yerine tutum, öz-yeterlik, ilgi ve kaygı düzeyini belirleme gibi matematiği bir bütün olarak ele alan genel durumları ifade etmektedir (Çiltaş, Güler ve Sözbilir, 2012). Bunların yanı sıra inançlar (Toluk-Uçar ve diğer., 2010), stratejiler (Fujimura, 2001), teknoloji destekli matematik öğretimi (Ersoy, 2005), problem çözme becerisi (Heppner ve Lee, 2009), öğrenenden kaynaklı nedenler (Alkan, 2011), cinsiyet, sınıf, gelir düzeyi ve okul ortamı (Meece, 1996) gibi daha birçok faktörün öğrenme üzerindeki etkilerinin incelendiği çalışmalar da bulunmaktadır. Öğrenme üzerindeki etkisi yadsınamaz olan ve yürütülen çalışmanın temel çıkış noktasını oluşturan öğrenenlerin öğrenme sürelerinin farklılı̆̆ öğrenme hızı da bunlardan bir tanesidir. Nitekim her bir öğrenenin algılama ve hazırbulunuşluk düzeyi gibi faktörler öğrenenin öğrenme hedef davranışlarına ulaşma sürelerini doğrudan etkilemektedir. Bu durum bilginin organizasyonu ile öğrenmenin doğasına ilişkin inançları yani öğrenmenin hızı ile yakından ilgilidir 
(Kardash ve Howell, 2000). Bu durumda her bir bireyin sinıf ortamındaki öğrenme miktarları da farklılık gösterebilir. Dolayısıyla öğrenenlerin zamana bağlı öğrenme güçlüklerinin nasıl değiştiği sorusuna yönelik kuramsal bir açıklamanın izleri aranabilir. Öğrencilerin bir kazanımda veya bir konuda yaşadıkları güçlükleri bilmek, öğrenmenin doğasını anlamada önemli bir adımdır. Böyle bir anlayışın en önemli yansıması gelecek müfredatların düzenlenmesine ve öğretim modellerinin oluşturulmasına dayanak sağlamasıdır (Rasmussen, 1998).

Tall ve Razali’ye (1993) göre, matematikte yaşanan öğrenme güçlükleri genel olarak temel kavramların yetersiz bir şekilde kavranmamasından, sözel problemleri matematiksel olarak formülize etmedeki yetersizlik ile cebirsel, geometrik ve trigonometrik becerilerdeki eksiklikten kaynaklanmaktadır. Tatar ve Dikici (2008) ise yaşanan öğrenme güçlüklerini uygulanan matematik öğretimindeki eksikliğe, konuların soyutluğuna, sözel ifadeleri yorumlayamama ile öğrencilerin hazırbulunuşluk düzeylerindeki yetersizliğe bağlamaktadır. Yürütülen çalışmanın en önemli nedenlerinden biri de öğrenme güçlüğü ile zaman arasındaki değişimi ortaya çıkaracak bir yapı (parametre) oluşturmaktır. Çalışmada yer verilen öğrenme güçlüğü öğrencilerin kazanımdan elde ettikleri puanlardan hareketle zaman ile öğrenme miktarına bağlı olarak değişen parametre değerleri olarak ele alınmıştır. Bu bağlamda, altıncı sınıf düzeyindeki yürütülen çalışmada "kesirlerle işlem yapmayı gerektiren problemleri çözer" kazanımı ele alınmıştır. Konu seçimi yapılırken hem öğrencilerin zorlandıkları bir konu olması hem de çalışmadan önce öğrencilerin ilgili konuyu öğrenmiş olmaları dikkate alınmıştır.

Alanyazın incelendiğinde, kesirler konusu ile ilgili çok sayıda çalışmaya rastlamak mümkündür (Altıparmak ve Özüdoğru, 2015; Biber, Tuna ve Aktaş, 2013; Charalambous ve Pitta-Pintazi, 2005; Haser ve Ubuz, 2002; Işık ve Kar, 2012; Kocaoğlu ve Yenilmez, 2010; Küçük ve Demir, 2009; Pesen, 2008; Soylu ve Soylu, 2005; Steffe ve Olive, 2010). Yürütülen çalışmaların ortak noktası ise kesirler konusunun öğrenciler için matematiğin anlaşılması en güç ve en soyut konularından birisi olmasıdır (Brown ve Quinn, 2006; Işık ve Kar, 2012; Misquitta, 2011). Nitekim Ulusal Matematik Danışma Üyeleri [The National Mathematics Advisory Panel] topluluğunun son raporuna göre, ortaokul öğrencilerinin \%40'1 temel düzeyde kesir kavramını anlamakta güçlükler yaşamaktadır (Akt. Misquitta, 2011). Örneğin Soylu ve Soylu (2005) beşinci sınıf düzeyinde 56 öğrenci üzerinde 8 soruluk bir test uygulayarak öğrencilerin kesirler konusunda yaşadıkları güçlükleri belirlemeye çalışmışlardır. Çalışma sonucunda; kesirlerde sıralama, toplama, çıkarma, çarpma ve kesir problemleri ile ilgili kavramların, tanımlarının ve formüllerinin öğrenilmesinde ve işlemsel bilgilerde öğrencilerin zorluk yaşamadığı ancak ezberledikleri tanımların ve kavramların uygulamalarında zorluklar yaşadıkları görülmüştür. Biber ve diğer., (2013) tarafindan 30 öğrenci üzerinde yapılan çalışmada öğrencilerin en önemli öğrenme güçlükleri; kesirlerde sıralama, toplama-çıkarma ve çarpma ile ilgili konularda kesirlerin pay ve paydalarını ayrı ayrı düşünüp işlem yapmaları, kesirlerle ilgili daha önce öğrenmiş oldukları kuralları daha sonraki konulara da 
uygulamaları olarak belirlenmiştir. Ayrıca kesir problemlerinde hatalı çözüm üreten öğrencilerin çoğu soruyu sadece işlem yaparak çözme yolunu seçtikleri ve zaten bu konuda kavram yanılgısına sahip oldukları için doğru sonucu elde edemedikleri gözlenmiştir. Diğer bir çalışma, Haser ve Ubuz (2002) tarafindan 145 öğrencinin kesirler konusundaki kavramsal ve işlemsel performanslarını belirlemeye yönelik yürütülmüştür. Öğrencilerin kavramsal performansa yönelik sorularda kesir tanımı ve gösterimleri ile ilgili durumlarda eş parçalara ayırma kuralını göz ardı ettikleri, denklik kavramını tam olarak anlayamadıkları, kesirlerle çarpma, toplama ve çıkarma yapmaya yönelik sorularda ise doğal sayılarda edindikleri işlem alışkanlıklarını devam ettirme eğiliminde oldukları belirlenmiştir. Ayrıca işlemsel performansa yönelik sorularda kesirler arasında çarpma ve çıkarma işlemlerinde, toplama işlemine göre düşük performansa sahip oldukları gözlenmiştir. Benzer şekilde, Işık ve Kar (2012) tarafından 210 yedinci sınıf öğrencisinin kesirlerde toplama işlemine yönelik kurdukları problemlerde karşılaşabilecekleri olası güçlükler belirlenmeye çalışılmıştır. Çalışma sonunda, öğrencilerin toplanan ikinci kesir bütünün kalanı üzerinden ifade etme, parçabütün ilişkisini kuramama, işlem sonucuna doğal sayı anlamı yükleme, birim kargaşası, toplanan kesir sayılarına doğal sayı anlamı yükleme, işlemi soru köküne yansıtamama, tamsayılı kesirlerin tam kısımlarına anlam yükleyememe şeklinde yedi güçlük rapor edilmiştir. Altıparmak ve Özüdoğru (2015) tarafindan yürütülen başka bir çalışmada öğrencilerin kesir konusundaki hata ve kavram yanılgıları ortaya çıkarılmaya çalışılmıştır. 37 sorudan oluşan "hata ve kavram yanılgıları teşhis testi”, 73 ortaokul ile 113 üniversite öğrencisine uygulanmıştır. Elde edilen bulgular, bir bütünün eş olmayan parçalara ayrılmasında, parça bütün üzerinde genişletme ve sadeleştirmede, sayı doğrusunu parça bütün olarak görme konusunda, toplama işlemi için eş olmayan bütünlerin kullanılması ile paydası eşit olmayan kesirlerde toplama yapılırken paylar toplanıp paya, paydalar toplanıp paydaya yazılan kavram hataları olduğuna işaret etmiştir.

Yürütülen çalışmaların genellikle öğrencilerin hata ve kavram yanılgıları üzerinden kurgulandığı ve öğrencilerin kesirler konusunda yaşadığı güçlükleri konu aldığı görülmektedir. Kesirlerle işlemler konusuna yönelik ders saati süresinin uygunluğu konusunda alanyazında herhangi bir çalışmaya rastlanılmamıştır. Oysa Özer ve Anıl (2011) tarafından 15 yaş grubu 4942 öğrenci üzerinde yürütülen çalışmanın bulguları, öğrencilerin matematik başarısını en çok yordayan değişkenin "öğrenmeye ayırdıkları zaman” değişkeni olduğuna işaret etmektedir. Bu sebeple öğrenme hedeflerine ulaşmada öğrenme ders süresinin etkin kullanımı ön plana çıkmaktadır. Özellikle ilk ve orta okullarda matematik dersi için önerilen ders süresi (matematik öğretilen müfredat süresi) müfredatta bir konunun diğerlerine nazaran önemini açıklamaya yardımcı olan önemli bir nitelik olmasının yanı sıra öğretilenin konunun zorluk derecesi veya öğrenenin algılama düzeyi ile yakından ilintilidir (Eurydice, 2011). $\mathrm{Bu}$ yüzden yürütülen çalışmanın hem bu boşluğu doldurması hem de ilgili kazanımlar için belirlenen ders saati sürelerinin öğrenen açısından önemini ortaya koyması beklenmektedir. 
Sonuç olarak, ülkemiz altıncı sınıf matematik öğretim programında ele alınan "kesirlerle işlem yapmayı gerektiren problemleri çözer" kazanımına ayrılan ders saatinin ortalama süresi 2.66 ders saatine karşılık gelmektedir (MEB, 2013). Bilindiği üzere, öğretim programında kazanımlara yönelik detaylı ders saati sürelerine yer verilmemektedir. Ders saati sürelerinin belirlenmesinde genellikle yıllık plandan hareketle kazanımların ağırlığına göre hareket edildiğinden her bir kazanım için ayrılacak ders saati süresi farklılık gösterebilir. $\mathrm{Bu}$ bakımdan ders saati sürenin belirlenmesinde, "ders saati süresi/kazanım sayısı" oranı dikkate alınarak her bir kazanıma ayrılabilecek ortalama ders saati süresi belirlenmiştir. $\mathrm{Bu}$ doğrultuda, belirlenen ders saati süresinin öğrencilerin öğrenme güçlüklerini nasıl yansıttığı ile öğrenme grubu veya tek bir öğrenenin ne kadarlık bir öğrenme düzeyine ulaştığı sorularından hareketle bu çalışmanın amacı, altıncı sınıf öğrencilerinin kesirlerle işlem yapmayı gerektiren problemleri çözer kazanımına göre zamana bağlı yaşadıkları öğrenme miktarları ile güçlüklerini belirlemektir.

\section{YÖNTEM}

$\mathrm{Bu}$ bölümde araştırmanın modeli, çalışma grubu, veri toplama aracı, verilerin analizi ile öğrenmeyi modelleyen formülün kullanılışı hakkında genel bilgilere yer verilmiştir.

\subsection{Araştırma Modeli}

Betimsel bir yaklaşımın benimsendiği çalışma genel ve tekil tarama modellerine göre yürütülmüştür. Genel tarama modelleri, çok sayıda elemandan oluşan bir evrende, evren hakkında genel bir yargıya varmak amaciyla evrenin tümü ya da ondan alınacak bir grup, örnek ya da örneklem üzerinde yapılan tarama düzenlemeleridir (Karasar, 2009). Bundan dolayı genel tarama modelleri ile aynı zamanda tekil taramalar da yapılabilmektedir. Tekil tarama modelleri ile anlık durum saptamaları yanında zamansal gelişimler ile değişimler de belirlenebilmektedir (Karasar, 2009).

\section{2. Çalışma Grubu}

Araştırmanın çalışma grubunu 2015-2016 eğitim-öğretim yılında İzmir şehir merkezindeki bir devlet ortaokulunda öğrenim gören 80 (\%54.1) k1z ve 68 (\%45.9) erkek olmak üzere toplam 148 altıncı sınıf öğrencisi oluşturmaktadır. Ölçme aracı seçkisiz örnekleme yöntemi ile seçilen on iki şube içinden altı şubeye uygulanmıştır. Çalışma "sayılar ve işlemler" öğrenme alanı anlatıldıktan sonra yapılmış ve aşağıdaki alt problemlere yanıt aranmıştır:

i) Öğrenme grubunun (148 öğrenci) zamana bağlı öğrenme güçlüğünün,

ii) Üst, orta ve alt düzey öğrenme seviyelerinde yer alan üç öğrencinin zamana bağlı öğrenme güçlüklerinin belirlenmesi.

Öğrenci sıralaması oluşturulurken öğrencilerin ölçme aracından aldıkları puanlar büyükten küçüğe doğru ve katılımcı sırası verilerek yapılmıştır. Örneğin en yüksek puan alan öğrencilerinden biri "Katılımcı 1" [K1] olarak belirtilmiştir. Ayrıca puanların frekansları dikkate alınarak ölçme aracı; üst [48-28], orta [2712] ve alt [11-3] öğrenme düzeylerini nitelendirecek şekilde puan aralıklarına 
ayrılmıştır. Üst düzey öğrenme seviyesi için $\mathrm{K} 1$, orta düzey öğrenme seviyesi K58 ve alt düzey öğrenme seviyesi için K148 öğrencileri seçilmiştir. Öğrenci seçimleri yapılırken öğrencilerin ölçme aracından aldıkları toplam puan dikkate alınmıştır. Her bir öğrencinin ölçme aracından aldığı puana ait dağılım durumun daha anlaşılır kılınması için aşağıdaki tabloda sunulmuştur.

Tablo 1. Katılımcı öğrencilerin ölçme aracından aldıkları puanlar

\begin{tabular}{|c|c|c|c|c|c|c|c|c|c|c|c|}
\hline Sira & Puan & Sira & Puan & Sira & Puan & Sira & Puan & Sira & Puan & Sira & Puan \\
\hline K1 & 48 & K26 & 38 & K51 & 27 & K76 & 18 & K101 & 12 & K126 & 7 \\
\hline $\mathrm{K} 2$ & 47 & K27 & 38 & K52 & 26 & K77 & 17 & K102 & 11 & K127 & 6 \\
\hline $\mathrm{K} 3$ & 46 & K28 & 38 & K53 & 26 & K78 & 17 & K103 & 11 & K128 & 6 \\
\hline $\mathrm{K} 4$ & 46 & K29 & 38 & K54 & 25 & K79 & 16 & K104 & 11 & K129 & 6 \\
\hline K5 & 46 & K30 & 37 & K55 & 25 & K80 & 16 & K105 & 11 & K130 & 6 \\
\hline K6 & 45 & K31 & 37 & K56 & 25 & K81 & 16 & K106 & 11 & K131 & 6 \\
\hline K7 & 45 & K32 & 37 & K57 & 24 & K82 & 16 & K107 & 10 & K132 & 6 \\
\hline K8 & 44 & K33 & 36 & K58 & 24 & K83 & 15 & K108 & 10 & K133 & 6 \\
\hline K9 & 44 & K34 & 36 & K59 & 24 & K84 & 15 & K109 & 10 & K134 & 6 \\
\hline K10 & 44 & K35 & 36 & K60 & 23 & K85 & 15 & K110 & 10 & K135 & 5 \\
\hline K11 & 43 & K36 & 35 & K61 & 23 & K86 & 15 & K111 & 10 & K136 & 5 \\
\hline K12 & 42 & K37 & 35 & K62 & 22 & K87 & 15 & K112 & 10 & K137 & 5 \\
\hline K13 & 42 & K38 & 34 & K63 & 21 & K88 & 14 & K113 & 10 & K138 & 5 \\
\hline K14 & 42 & K39 & 33 & K64 & 20 & K89 & 14 & K114 & 10 & K139 & 5 \\
\hline K15 & 41 & K40 & 33 & K65 & 20 & K90 & 14 & K115 & 9 & K140 & 5 \\
\hline K16 & 41 & K41 & 32 & K66 & 20 & K91 & 14 & K116 & 9 & K141 & 5 \\
\hline K17 & 41 & $\mathrm{~K} 42$ & 32 & K67 & 20 & K92 & 14 & K117 & 9 & K142 & 5 \\
\hline K18 & 41 & K43 & 32 & K68 & 20 & K93 & 13 & K118 & 9 & K143 & 4 \\
\hline K19 & 41 & K44 & 31 & K69 & 19 & K94 & 13 & K119 & 9 & K144 & 4 \\
\hline $\mathrm{K} 20$ & 40 & K45 & 31 & K70 & 19 & K95 & 13 & K120 & 8 & K145 & 4 \\
\hline K21 & 40 & K46 & 30 & K71 & 19 & K96 & 12 & K121 & 8 & K146 & 4 \\
\hline K22 & 39 & K47 & 30 & K72 & 18 & K97 & 12 & K122 & 7 & K147 & 4 \\
\hline K23 & 39 & K48 & 29 & K73 & 18 & K98 & 12 & K123 & 7 & K148 & 3 \\
\hline K24 & 39 & K49 & 29 & K74 & 18 & K99 & 12 & K124 & 7 & & \\
\hline K25 & 39 & K50 & 28 & K75 & 18 & K100 & 12 & K125 & 7 & & \\
\hline
\end{tabular}

\subsection{Veri Toplama Aracı}

Veri toplama aracı; literatür, öğretmen ve ortaokul altıncı sınıf matematik ders kitabı desteğiyle hazırlanan doğal sayılarla işlemler ünitesini içeren problemlerden oluşmaktadır. Soruların hazırlanmasında 2015-2016 eğitimöğretim yilında okutulan ve Talim Terbiye Kurulunca kabul edilen ortaokul altıncı sınıf matematik ders kitabından yararlanılmıştır (Bağcı, 2015). Ayrıca oluşturulan sorular için uzman görüşleri alınmıştır. Hazırlanan problemlerin ölçme aracına uygun olup olmadığı, ölçülmek istenen alanı temsil edip etmediği uzman görüşüne göre saptanır (Karasar, 2009). Öncelikle matematik eğitimi uzmanları tarafindan ölçme aracının amacına, içeriğine ve çözümlemelerine göre aday sorular hazırlanmış, oluşturulan problemlerin bu amaçları ve içeriği temsil edip etmediği tartışılmıştır. Daha sonra üç matematik öğretmenine ve üç alan eğitimcisine gösterilerek açık uçlu problemlerle ilgili öğrencilerin farklı anlam yüklemesine neden olabileceği düşünülen maddeler üzerinde önerileri doğrultusunda düzeltmeler/düzenlemeler yapılmıştır. Bu sayede sorulara ait dil, içerik, uygunluk ve kapsam geçerliliği sağlanmıştır. 
Son şekli verilen ilk forma ait sorular aynı okulda öğrenim gören ancak çalışma grubundan farklı olan 15 öğrenci üzerinde denenerek pilot çalışma yapılmıştır. Pilot çalışma sayesinde öğrencilerin anlamakta zorlandıkları noktalar tespit edilmiş ve gerekli düzeltmeler yapılmıştır. Bunların yanı sıra geliştirilen veri toplama aracının yapı geçerliğini test etmek için doğrulayıcı faktör analizi gerçekleştirilmiştir $\left[\mathrm{x}^{2}=113.736 ; \mathrm{p}<0.01 ; \mathrm{x}^{2} / \mathrm{sd}=2.14 ; \mathrm{CFI}=0.96 ; \mathrm{RMSEA}=0.08\right.$; $\mathrm{IFI}=0.96 ; \mathrm{GFI}=0.89 ; \mathrm{AGFI}=0.84 ; \mathrm{NFI}=0.93$ ]. Tüm faktörler istatistiksel olarak anlamlı bulunmuş ve uyum indeksleri sonucunda elde edilen modelin iyi bir uyuma sahip olduğunu ortaya koymuştur. 12 soruluk nihai ölçme aracinın Cronbach Alpha ölçüm güvenirlik katsayısı $0.95(\mathrm{n}=160)$ olarak hesaplanmıştır. Öğrenmenin niteliğini belirlemeye yönelik hazırlanan sorular, ilgili kazanımın karakteristik özelliğini ortaya çıkaracak şekilde hazırlanmış ve gerekli düzeltmelerin ardından ölçme aracı uygulamaya hazır hale getirilmiştir. Her sorunun eşit puana sahip olduğu ölçme aracından alınabilecek maksimum puan 48 , minimum puan ise 0 olarak belirlenmiştir. Öğretim programında alt öğrenme alanı kesirlerle işlemler olan dokuz kazanıma ayrılan süre yaklaşık 24 ders saati olarak belirtilmiştir (MEB, 2013). Bu durumda çalışmada yer verdiğimiz kazanımda dâhil olmak üzere her bir kazanım için ayrılan süre ise ortalama 2.66 ders saatinden oluşmaktadır. İlgili kazanıma uygun olarak hazırlanmış örnek problemler ile ait olduğu kazanım aşağıdaki tabloda sunulmuştur.

Tablo 2. Örnek sorular ve ilgili kazanım

\begin{tabular}{|c|c|}
\hline Sorular & Kazanım \\
\hline $\begin{array}{l}\text { Bir hayvanat bahçesindeki } 150 \text { tane hayvandan } 1 / 5 \text { 'i deve, } 1 / 6 \text { 's1 } \\
\text { ceylan, geri kalanı maymundur. Buna göre, hayvanat bahçesindeki } \\
\text { maymunların sayısı kaçtır? Çözümünüzü ayrıntıll şekilde yapınız. }\end{array}$ & \multirow{4}{*}{$\begin{array}{l}\text { Kesirlerle İşlemler: } \\
\text { Kesirlerle işlem } \\
\text { yapmayl gerektiren } \\
\text { problemleri çözer. }\end{array}$} \\
\hline $\begin{array}{l}\text { Bir çiftlikteki hayvanların 2/9’u koyun, 3/10’u inek, 7/30’u tavuk } \\
\text { geri kalanı ise keçidir. Çiftlikte toplam } 360 \text { hayvan olduğuna göre, } \\
\text { çiftlikteki keçi sayısı kaçtır? Çözümünüzü ayrıntılı şekilde yapınız. }\end{array}$ & \\
\hline $\begin{array}{l}\text { Çiftçi Tahsin amca tarlasının 1/6'sına biber, 2/5'ine soğan ve } \\
1 / 30 \text { 'una lahana ekiyor. Geriye ekilecek } 100 \mathrm{~m}^{2} \text { alan kaldığına göre } \\
\text { soğan ektiği alan kaç m² dir? Çözümünüzü ayrıntıll şekilde yapınız. }\end{array}$ & \\
\hline $\begin{array}{l}\text { Bir akvaryumdaki balıkların 3/7'si turuncu renkli ve diğerleri beyaz } \\
\text { renklidir. Beyaz renkli balıkların sayıs1 } 16 \text { olduğuna gore, turuncu } \\
\text { renkli balıkların sayısı kaçtır? Çözümünüzü ayrıntılı şekilde yapınız. }\end{array}$ & \\
\hline
\end{tabular}

\subsection{Verilerin Analizi}

Ölçme aracının geliştirilmesinde SPSS 20.00 [Statistical Package for the Social Sciences] ile IBM SPSS Amos paket programı, grafiklerin çiziminde ise Graph programı kullanılmıştır. Ortaokul Matematik Dersi (5, 6, 7 ve 8. Sınıflar) Öğretim Programı'ndaki (MEB, 2013) öğrenme alanı sayılar ve işlemler, kesirlerle işlemler yapma alt öğrenme alanı içerisinde yer alan kesirlerle işlem yapmayı gerektiren problemleri çözer kazanımını içeren 12 tane açık uçlu sorunun çözümlenmesinde Marzano’un (2000) geliştirmiş olduğu dereceli (aşamalı) puan ölçeği kullanılmıştır. Bu bağlamda, gözlenen öğrenci davranışına göre verilecek puanların açıklamaları aşağıda sunulmuştur (bkz. Tablo 3). 
Tablo 3. Dereceli puan ölçeği

\begin{tabular}{lc}
\hline \multicolumn{1}{c}{ Gözlenen Öğrenci Davranışı (Ölçütler) } & Puan \\
\hline $\begin{array}{l}\text { Bir engelin veya zorluğun üstesinden gelmede en etkili çözüm yolunu seçer ve } \\
\text { bunun olası çözüm yolları içerisinde neden en etkilisi olduğunu tam olarak } \\
\text { açıklar. }\end{array}$ & 4 \\
\hline $\begin{array}{l}\text { Bir engelin veya zorluğun üstesinden gelmede en etkili çözüm yolunu seçer ve } \\
\text { bunun olası çözüm yolları içerisinde neden en etkilisi olduğunu tam olarak }\end{array}$ & 3 \\
açıklayamaz. & \\
\hline $\begin{array}{l}\text { Bir engelin veya zorluğun üstesinden gelmede doğru bir çözüm yolu seçer ama } \\
\text { bu en etkili olan değildir ve vermiş olduğu cevap çözüm sürecini kısmen de olsa } \\
\text { gösterir. }\end{array}$ & 2 \\
\hline $\begin{array}{l}\text { Seçmiş olduğu çözüm yolu engelin veya zorluğun üstesinden gelebilecek } \\
\text { nitelikte değildir. }\end{array}$ & 1 \\
\hline Hiçbir yargıda bulunmaz. & \\
\hline
\end{tabular}

Öğrencilere yöneltilen 12 soruluk açık uçlu problemlere verilen cevaplar nicel veriler haline dönüștürülüp analiz edilmiştir. Öğrencilerin sorulara vermiş oldukları yanıtlar 0 ile 4 arasında değişen derecelendirilmiş puanlama anahtarı ile değerlendirilmiştir. Örneğin öğrenci problemi tam olarak anlayamamış, çözüme katkıda bulunacak bilgiye yer vermemiş, çok sayıda hatalar yapmış, ilgisiz çıkarımda bulunmuş, konu hakkında bilgisiz ve izlediği yöntem çözüme uygun değilse bir puan almıştır. Çözüme kısmen katkıda bulunmuş, tümüyle değilse de önemli hatalar yapmış, problemi kısmen anlamış, izlediği yöntem uygun ancak eksiklikleri varsa iki puan almıştır. Yeterli düzeyde çözüme katkı sağlamış, problemin kendisinden ne istediğini anlamış, çözüme yönelik uygulamalar sergilemiş ve çözüm yolu belirginse üç puan almıştır. Doğru ve eksiksiz çıkarımda bulunmuş, yaratıcı ve çözüme fazlasıyla katkıda bulunmuş, derin ve farklı bakış açılarını problem üzerinde yansıtmış, çözüme yönelik değerli bilgiler sunmuş, eksiksiz yorum ve açılamalar yapmışsa dört puan almıştır. Herhangi bir cevap vermemiş ya da alakasız yanıtlar sunmuşsa sıfir puan almıştır. Diğer yandan zamana bağlı öğrenme miktarını belirlemek için psikolojide bir işin öğrenilmesi modelini belirleyen formülden faydalanılmıştır (Nagle, Saff ve Snider, 2013). Öğrenmeyi modelleyen formül aşă̆ıda verilmiştir:

$\checkmark \mathrm{n}=$ öğrenmenin niteliği (öğrenilen konuyu karakterize eden soru sayısı)

$\checkmark \mathrm{p}=$ kişinin niteliği (kazanım/kazanımlardan elde edilen başarı)

$\checkmark \mathrm{c}=$ kişisel öğrenmeye göre değişen sabit

$\checkmark \mathrm{y}=$ öğrenme miktarı

$\checkmark \mathrm{t}=$ zaman (kazanıma ait öğrenme süresi)

Öğrenmeyi Modelleyen Formül: $\frac{d y / d t}{\left(y-y^{2}\right)^{\frac{3}{2}}}=\frac{2 p}{\sqrt{n}} \Rightarrow \frac{4 y-2}{\sqrt{y-y^{2}}}=\frac{2 p}{\sqrt{n}} \cdot t+c$

Formülün Kullanılısı: Öncelikle öğretim programında ilgili konuyu karakterize eden kazanımlara göre, ölçme aracı oluşturulmuştur. Ölçme aracının geliştirilmesi için ilgili literatürün yanında uzman ve ders öğretmenlerinin görüşleri alınmış ve kazanımlara uygun olarak açı uçlu soru sayısı 
belirlenmiştir. Belirlenen soru sayısı öğrenmenin niteliği olarak kabul edilmiştir. Her bir öğrenenin veya grubun niteliğini belirlemek için ölçme aracından elde edilen puanlar dikkate alınmıştır. Diğer bir adımda grup ya da kişisel öğrenmeye göre değişen sabit değer bulunmuştur. Son olarak, belli bir değerde öğrenme miktarı alınarak zamana göre parametre değerleri incelenmiştir.

\section{BULGULAR}

$\mathrm{Bu}$ bölümde öğrenme grubu ile üst, orta ve alt öğrenme seviyesinde bulunan öğrencilerin zamana bağlı öğrenme güçlüklerinin belirlenmesine yönelik yapılan çözümlemeler sonucunda elde edilen bulgular ve ilgili yorumlara yer verilmiştir.

\section{1. Öğrenme Grubuna Ait Öğrenme Güçlüğü}

Aşağıda öğrenme grubuna ait zamana bağlı öğrenme güçlüğünü belirlemek için yapılan hesaplamalar yer almaktadır. Öğrenme grubu toplam 148 öğrenciden oluşmaktadır. Öğrenme grubuna ait nitelik, öğrenmenin niteliği, öğrenme miktarı, öğrenmeye ayrılan zaman ve bu bileşenlere bağlı olarak değişen sabit değerler şu şekildedir:

$\checkmark \mathrm{n}=12$ öğrenmenin niteliği (kazanımın karakteristik özelliğini yansıtan soru sayıs1)

$\checkmark p=3168 / 148=21.4$ öğrenme grubunun niteliği (kazanımdan elde edilen puan ortalamas1)

$\checkmark \mathrm{t}=1.25$ yarı öğrenme için gerekli ders saati/zaman (kazanım için ayrılan öğrenme süresi)

$\checkmark \mathrm{c}=$ öğrenme grubuna göre değişen keyfi sabit (parametre)

$\checkmark \mathrm{y}=1 / 2$ öğrenme miktarı (değişken)

Aşağıda öğrenme grubuna ait zamana bağlı öğrenme güçlüğünü belirlemek için yapılan hesaplamalar yer almaktadır.

y=1/2 yarı ögrenme miktarı için modelin kullanımı

$\frac{d y / d t}{\left(y-y^{2}\right)^{\frac{3}{2}}}=\frac{2 p}{\sqrt{n}} \Rightarrow \frac{4 y-2}{\sqrt{y-y^{2}}}=\frac{2 p}{\sqrt{n}} \cdot t+c \Rightarrow \frac{4 \cdot \frac{1}{2}-2}{\sqrt{\frac{1}{2}-\left(\frac{1}{2}\right)^{2}}}=\frac{2 \cdot 21,4}{\sqrt{12}} \cdot(1,25)+c \Rightarrow c \cong-15,46$

$\frac{4 y-2}{\sqrt{y-y^{2}}}+15,46=\frac{2.21,4}{\sqrt{12}} \cdot t \quad \Rightarrow \quad \sqrt{12} \cdot\left(\frac{4 y-2}{\sqrt{y-y^{2}}}+15,46\right)=42,8 . t$

$\frac{\sqrt{12} \cdot(4 y-2)}{42,8 \cdot \sqrt{y-y^{2}}}+\frac{\sqrt{12} \cdot 15,46}{42,8}=t \quad$ [zaman ve öğrenme miktarı arasındaki denklem]

Yarı öğrenme miktarından elde edilen verilerden hareketle öğrenme grubunun zamana bağlı öğrenme miktarı ile öğrenme güçlüğüne ilişkin grafikler aşağıda yer almaktadır. 


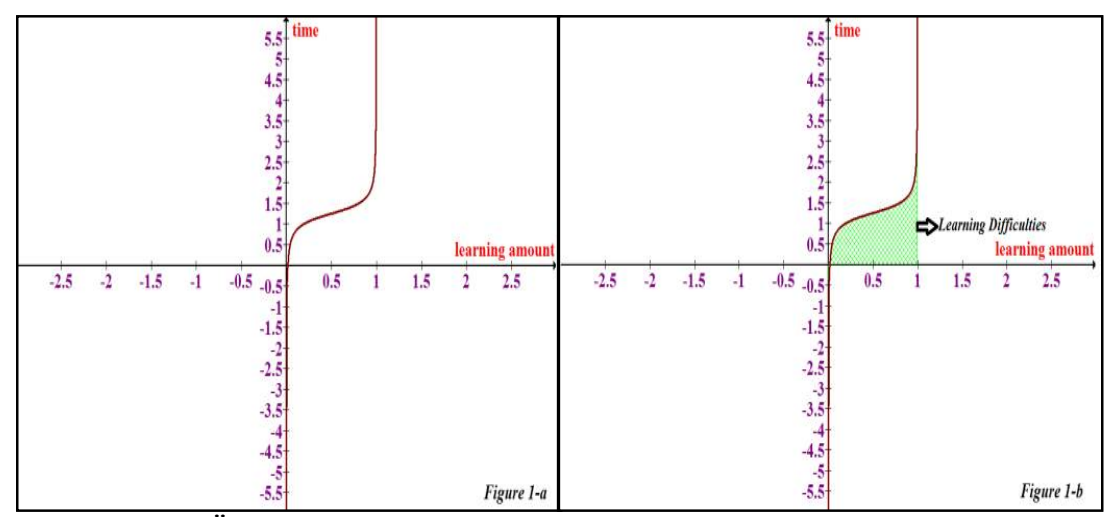

Şekil 1-a,b: Öğrenme grubunun zamana bağlı öğrenme miktarı ile öğrenme güçlüğüne ait grafikler

Tablo 4. Öğrenme grubuna ait öğrenme miktarı ile zaman arasındaki parametre değerleri

\begin{tabular}{lccccccccc}
\hline \multicolumn{10}{c}{ Öğrenme miktarı ile zaman arasındaki parametre değerleri } \\
\hline Öğrenme miktarı & 0.041 & 0.198 & 0.500 & 0.805 & 0.959 & 0.984 & $0.987^{*}$ & 0.990 & 0.999 \\
\hline Zaman & 0.5 & 1.0 & 1.25 & 1.5 & 2.0 & 2.5 & 2.66 & 2.84 & 6.4 \\
\hline
\end{tabular}

*Tam öğrenme miktarı düzeyi için alt sınır

Şekil 1-a ve Tablo 4 incelendiğinde, yarı öğrenme miktarının 1.25 ders saati zaman diliminde gerçekleştiği ancak öğrenme miktarı 0.987 olduğunda bu sürenin 2.66 ders saatine ulaştığı görülmektedir. Öğretim programında belirlenen kazanım için ayrılan sürenin ortalama 2.66 ders saati olduğu göz önüne alındığında öğrenme grubunun tam öğrenmeye ulaşması için 0.013'lük bir öğrenme miktarına daha ihtiyaç duyduğu görülmektedir. Ayrıca 0.987'lik bir öğrenme miktarı 2.66 ders saatine işaret ederken tam öğrenme düzeyine en yakın değer olan 0.999 öğrenme miktarında bu süre 3.74 ders saati bir artışla 6.4 ders saatine çıkmaktadır. Özellikle öğrenme miktarı ile zaman arasındaki parametre değerlerine ait Tablo 4 incelendiğinde, tam öğrenme düzeyine yaklaşıldıkça kazanım için ayrılması gereken sürenin de artış gösterdiği görülmektedir. Bununla birlikte eğrinin öğrenme miktarı eksenini kestiği negatif değerler bu grubun başlangıçta bir miktar öğrenme miktarına sahip olduğunu göstermektedir. Yürütülen çalışma kapsamında öğrenme miktarı düzeyi 0.987 alt sınır seviyesinde yer alan öğrenciler için tam öğrenme düzeyine ulaşılmış kabul edildiğinde öğrenme grubu öğrencilerinin öğretim müfredatı çerçevesinde tam öğrenme düzeyine ulaştıkları söylenebilir. Şekil 1-b incelendiğinde, zaman ile öğrenme miktarı arasında doğrusal olmayan bir bağıntının olduğu görülmektedir. Birim olarak zaman ile öğrenme miktarının çarpımı bir başka ifade ile eğrinin altında kalan alanı belirten bu bağıntı bize öğrenme grubunun sahip olduğu potansiyel durumu yani öğrenme güçlüğünü vermektedir. Eğrinin altında kalan alan azaldığında öğrenme grubunun sahip olduğu öğrenme gücü miktarında da azalmanın olduğu görülmektedir (Şekil 2-a,b,c,d). Bu durum öğrenmeye ayrılan 
sürenin azalmasıyla öğrenme grubunun daha az öğrenme güçlüğü yaşadığını göstermektedir. Eğrinin altında kalan alan arttığında öğrenme güçlüğü de artış göstermektedir. $\mathrm{Bu}$ durumun göstergesi olarak 0.154'lük (0.959-0.805) bir öğrenme miktarı değişimi için geçen sürenin 0.025'lik (0.984-0.959) bir öğrenme miktarı artışı ile eşit olması olarak gösterebiliriz. Tüm bu anlatılanlar 1şı̆̆ında, öğrenme güçlüğüne ait grafiklere ve parametre değerlerine aşağıda yer verilmiştir.

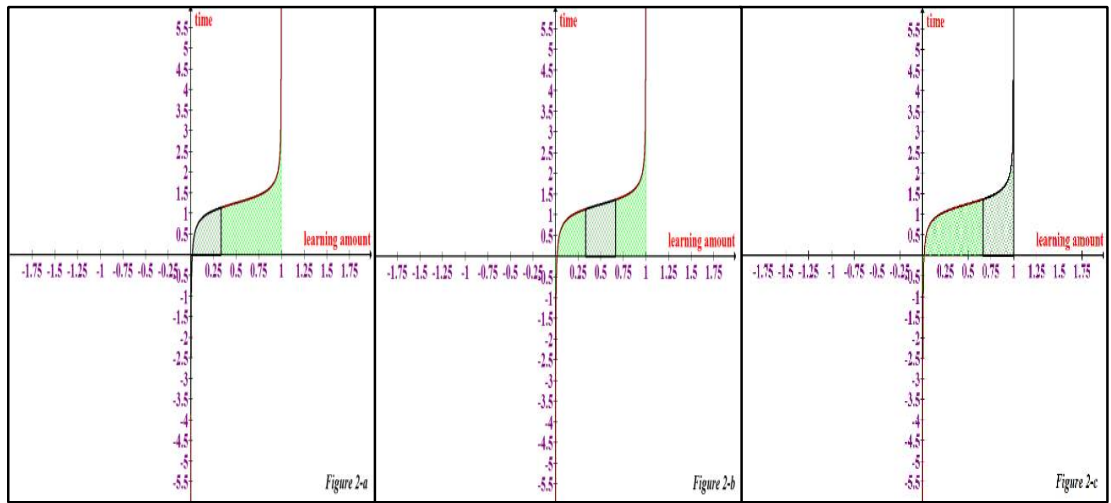

Şekil 2-a,b,c: Ö̆ğrenme grubunun öğrenme güçlüğüne ait grafikleri

Tablo 5. Öğrenme grubunun öğrenme güçlüğüne ait parametre değerleri

Öğrenme miktarı ile zaman arasında oluşan eğrinin altında kalan alana ait parametre değerleri

$\begin{array}{lllll}\text { Öğrenme miktar } & 0.001-0.333 & 0.333-0.666 & 0.666-0.999 & 0.001-0.999\end{array}$

aralı̆̆1

$\begin{array}{lllll}\text { Öğrenme } & 0.274 & 0.416 & 0.559 & 1.249\end{array}$

güçlüğü

Tablo 5'de yer alan öğrenme miktarı ile zaman eğrisinin altında kalan alana ait parametre değerleri incelendiğinde; öğrenme miktarı 0.001-0.333 aralığında iken öğrenme güçlüğü 0.274'ü, 0.333-0.666 aralığında iken 0.416'yı, 0.666-0.999 aralığında iken 0.559'u ve 0.001-0.999 aralığında iken öğrenme güçlüğü 1.249'u göstermektedir. Sonuç olarak, eğrinin altında kalan alanın artışına bağlı olarak öğrenciler daha fazla öğrenme güçlüğü yaşamaktadır.

\subsection{K1, K58 ve K148 Öğrencilerin Öğrenme Güçlüğü}

Aşağıda üst, orta ve alt düzey öğrenme seviyelerinde yer alan öğrencilerin öğrenme güçlüklerini belirlemek için yapılan hesaplamalar yer almaktadır.

K1, K58 ve K148 Öğrencileri İcin;

$\checkmark \mathrm{n}=12$ öğrenmenin niteliği (kazanımın karakteristik özelliğini yansıtan soru sayıs1)

$\checkmark$ p= 48 (K1 öğrenenin niteliği), 24 (K58 öğrenenin niteliği), 3 (K148 öğrenenin niteliği) 
$\checkmark \mathrm{t}=1.25$ yarı öğrenme için gerekli ders saati/zaman (kazanım için ayrılan öğrenme süresi)

$\checkmark \mathrm{c}=\mathrm{K} 1, \mathrm{~K} 58$ ve K148 öğrencilerine göre değişen keyfi sabit (parametre)

$\checkmark \mathrm{y}=1 / 2$ öğrenme miktarı (değişken)

\section{$\underline{\text { K1 ögrencisi için; } y=1 / 2 \text { yarl ögrenme miktarl }}$}

$\frac{d y / d t}{\left(y-y^{2}\right)^{\frac{3}{2}}}=\frac{2 p}{\sqrt{n}} \Rightarrow \frac{4 y-2}{\sqrt{y-y^{2}}}=\frac{2 p}{\sqrt{n}} \cdot t+c \Rightarrow \frac{4 \cdot \frac{1}{2}-2}{\sqrt{\frac{1}{2}-\left(\frac{1}{2}\right)^{2}}}=\frac{2.48}{\sqrt{12}} \cdot(1,25)+c \Rightarrow c \cong-34,68$

$\frac{4 y-2}{\sqrt{y-y^{2}}}+34,68=\frac{2.48}{\sqrt{12}} \cdot t \quad \Rightarrow \quad \sqrt{12} \cdot\left(\frac{4 y-2}{\sqrt{y-y^{2}}}+34,68\right)=96 . t$

$\frac{\sqrt{12} \cdot(4 y-2)}{96 \cdot \sqrt{y-y^{2}}}+\frac{\sqrt{12} \cdot 34,68}{96}=t \quad[\mathrm{~K} 1$ öğrencisinin zaman ve öğrenme miktarına ait denklem $]$

\section{K58 ögrrencisi için; $y=1 / 2$ yarı ögrenme miktarı}

$$
\begin{aligned}
& \frac{d y / d t}{\left(y-y^{2}\right)^{\frac{3}{2}}}=\frac{2 p}{\sqrt{n}} \Rightarrow \frac{4 y-2}{\sqrt{y-y^{2}}}=\frac{2 p}{\sqrt{n}} \cdot t+c \Rightarrow \frac{4 \cdot \frac{1}{2}-2}{\sqrt{\frac{1}{2}-\left(\frac{1}{2}\right)^{2}}}=\frac{2 \cdot 24}{\sqrt{12}} \cdot(1,25)+c \Rightarrow c \cong-17,34 \\
& \frac{4 y-2}{\sqrt{y-y^{2}}}+17,34=\frac{2.24}{\sqrt{12}} \cdot t \Rightarrow \sqrt{12} \cdot\left(\frac{4 y-2}{\sqrt{y-y^{2}}}+17,34\right)=48 \cdot t
\end{aligned}
$$

$\frac{\sqrt{12} \cdot(4 y-2)}{48 \cdot \sqrt{y-y^{2}}}+\frac{\sqrt{12} \cdot 17,34}{48}=t \quad[$ K58 öğrencisinin zaman ve öğrenme miktarına ait denklem $]$

\section{$\underline{\text { K148 ögrencisi için; } y=1 / 2 \text { yarl öğrenme miktarl }}$}

$$
\begin{aligned}
& \frac{d y / d t}{\left(y-y^{2}\right)^{\frac{3}{2}}}=\frac{2 p}{\sqrt{n}} \Rightarrow \frac{4 y-2}{\sqrt{y-y^{2}}}=\frac{2 p}{\sqrt{n}} \cdot t+c \Rightarrow \frac{4 \cdot \frac{1}{2}-2}{\sqrt{\frac{1}{2}-\left(\frac{1}{2}\right)^{2}}}=\frac{2.3}{\sqrt{12}} \cdot(1,25)+c \Rightarrow c \cong-2,16 \\
& \frac{4 y-2}{\sqrt{y-y^{2}}}+2,16=\frac{2.3}{\sqrt{12}} \cdot t \Rightarrow \sqrt{12} \cdot\left(\frac{4 y-2}{\sqrt{y-y^{2}}}+2,16\right)=6 \cdot t
\end{aligned}
$$

$\frac{\sqrt{12} \cdot(4 y-2)}{6 \cdot \sqrt{y-y^{2}}}+\frac{\sqrt{12} \cdot 2,16}{6}=t \quad[$ K148 öğrencisinin zaman ve öğrenme miktarına ait denklem $]$ 
Yarı öğrenme miktarından elde edilen verilerden hareketle, üst, orta ve alt düzey öğrencilerin zamana bağlı öğrenme miktarı ile öğrenme güçlüğüne ilişkin grafikler aşağıda yer almaktadır.

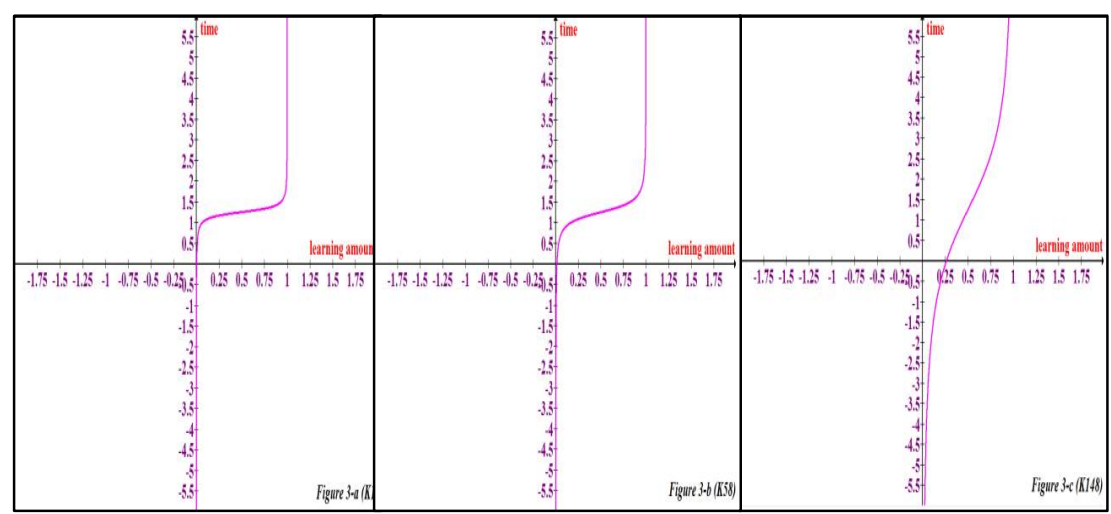

Şekil 3-a,b,c: K1, K58 ve K148 öğrencilerin öğrenme miktarlarına ait grafikler

Tablo 6. K1, K58 ve K148 öğrencilerine ait öğrenme miktarı-zaman arasındaki parametre değerleri

\begin{tabular}{lccccccccc}
\hline \multicolumn{1}{c}{ K1 öğrencisi için öğrenme miktarı ile zaman arasındaki parametre değerleri } \\
\hline Öğrenme miktarı & 0.009 & 0.069 & 0.500 & 0.933 & $0.987^{*}$ & 0.991 & 0.995 & 0.997 & 0.999 \\
Zaman & 0.5 & 1.0 & 1.25 & 1,5 & 1.8 & 2.0 & 2.2 & 2.5 & 3.53 \\
\hline \multicolumn{2}{c}{ K58 öğrencisi için öğrenme miktarı ile zaman arasındaki parametre değerleri } \\
\hline Öğrenme miktarı & 0.034 & 0.172 & 0.500 & 0.827 & 0.967 & 0.976 & $0.987^{*}$ & 0.988 & 0.999 \\
Zaman & 0.5 & 1.0 & 1.25 & 1.5 & 2.0 & 2.15 & 2.49 & 2.54 & 5.81 \\
\hline
\end{tabular}

K148 öğrencisi için öğrenme miktarı ile zaman arasındaki parametre değerleri

\begin{tabular}{lccccccccc}
\hline Öğrenme miktarı & 0.347 & 0.447 & 0.500 & 0.555 & 0.655 & 0.739 & 0.803 & $0.987^{*}$ & 0.999 \\
Zaman & 0.5 & 1.0 & 1.25 & 1.5 & 2.0 & 2.5 & 3.0 & 11.17 & 37.70
\end{tabular}

*Tam öğrenme miktarı düzeyi için alt sınır

Şekil 3-a,b,c ve Tablo 6'da verilen parametre değerleri incelendiğinde, K1 öğrencisi 0.5 ders saati zaman diliminde 0.009 , K58 öğrencisi 0.034 ve K148 öğrencisi ise 0.347 öğrenme miktarına ulaşmaktadır. Yarı öğrenme miktarına ise K1, K58 ve K148 öğrencileri aynı sürede ulaşmışlar ancak tam öğrenme miktarı düzeyi için belirlenen alt sınır seviyesine K1 öğrencisi 1.8, K58 öğrencisi 2.49 ve K148 öğrencisi 11.17 ders saatinde ulaşabilmiştir. Bu sonuçlara göre, tam öğrenme düzeyine yaklaşıldıkça öğrenme miktarındaki artışın az olmasına rağmen öğrenme için gerekli olan sürenin miktarındaki artış özellikle K148 öğrencisi için daha belirgin olarak göze çarpmaktadır. Örneğin tam öğrenme seviyesine en yakın değer olan 0.999'a K1 öğrencisi 3.53, K58 öğrencisi 5.81 ve K148 öğrencisi ise 37.70 ders saati diliminde ulaşabilmiştir. Ayrıca K1 ve K58 öğrencileri tam öğrenme seviyesine yakın bir değerde ortalama ders saati zaman bandında yer alırken K148 öğrencisi ise bu zaman bandının çok uzağında kalmıştır. 


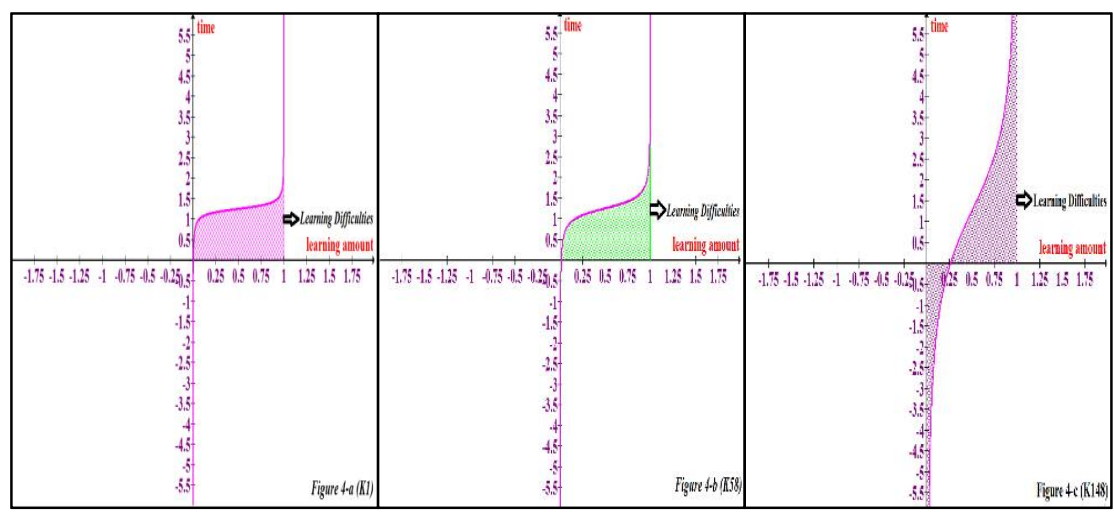

Şekil 4-a,b,c: K1, K58 ve K148 öğrencilerin öğrenme güçlüğüne ait grafikleri

Tablo 7. K1, K58 ve K148 öğrencilerin öğrenme güçlüğüne ait parametre değerleri

\begin{tabular}{lcccc}
\hline $\begin{array}{l}\text { Öğrenme miktarı ile zaman arasında oluşan eğrinin } \\
\text { parametre değerleri }\end{array}$ & & & & \\
\hline Öğgrenme miktar aralığı & $0.001-0.333$ & $0.333-0.666$ & $0.666-0.999$ & $0.001-0.999$ \\
\hline K1 öğrencisi & 0.352 & 0.416 & 0.480 & 1.248 \\
\hline K58 öğrencisi & 0.288 & 0.416 & 0.543 & 1.248 \\
\hline K148 öğrencisi & $0.616^{*}$ & 0.414 & 1.431 & 2.461 \\
\hline
\end{tabular}

*Negatif değer aralıklarındaki alana ait değer

Tablo 7'de yer alan öğrenme miktarı ile zaman eğrisinin altında kalan alana ait parametre değerleri incelendiğinde; öğrenme miktarı 0.001-0.333 aralığında iken K1 öğrencisinin öğrenme güçlüğü 0.323 'ü, K58 öğrencisi için 0.288 'i ve K148 öğrencisi için 0.616 'yı göstermektedir. 0.333-0.666 aralığı için K1 ve K58 öğrencilerinin öğrenme güçlüğü 0.416 'y1, K148 öğrencisi için 0.414'ü göstermektedir. 0.666-0.999 aralığ1 için K1 öğrencisinin öğrenme güçlüğü 0.480 'i, K58 öğrencisi için 0.543 'ü ve K148 öğrencisi için 1.431 'i göstermektedir. 0.001-0.999 aralığında ise K1 ve K58 öğrencilerin öğrenme güçlüğü 1.248 'i ve K148 öğrencisi için 2.461'i göstermektedir. Bu bağlamda, eğrinin altında kalan alanın artışına bağlı olarak öğrenciler daha fazla öğrenme güçlüğü yaşamaktadır.

\section{TARTIŞMA, SONUÇ VE ÖNERILLER}

$\mathrm{Bu}$ bölümde, kesirlerle işlem yapmayı gerektiren problemleri çözer kazanımının ele alındığı $80 \mathrm{kız}$ ve 68 erkek olmak üzere toplam 148 öğrenciden oluşan öğrenme grubu ile K1, K58 ve K148 öğrencilerin zamana bağlı öğrenme miktarlarından hareketle öğrenme güçlüklerinin belirlenmeye çalışıldığ araştırma sonuçları 1şı̆̆ında elde edilen bulgular yorumlanmıştır. Ortaokul Matematik Dersi Öğretim Programı'nda öğrenme alanı sayılar ve işlemler, alt öğrenme alanı kesirlerle işlemler yapma ile ilgili kesirlerle işlem yapmayı gerektiren problemleri çözer kazanımını için ayrılan süre ortalama 2.66 ders saati süresi olarak belirtilmiştir (MEB, 2013). Çalışmada öğrenme grubu olarak 
nitelendirilen toplam 148 öğrenci bu kazanım için 2.66 ders saatlik bir zaman diliminde 0.987 öğrenme miktarına ulaşmıştır. Elde edilen bu miktar, sonuçların daha anlaşılır kılınması için hem öğrenme grubu hem de K1, K58 ve K148 öğrencileri için öğrenme miktarının alt sınır seviyesi olarak belirlenmişstir. $\mathrm{Bu}$ kapsamda, öğrenme grubundan elde edilen veriler, öğrencilerin tam öğrenme seviyesinden 0.013 'lük kadar gerisinde kaldığını göstermektedir. Öğrenme miktarında meydana gelen bu küçük sapmaya rağmen tam öğrenme düzeyine en yakın değer için 6.4 ders saatlik bir zaman dilimine ihtiyaç duyulmaktadır. $\mathrm{Bu}$ süre 2014 yılı 29118 sayılı Resmi Gazetede yayınlanan Milli Eğitim Bakanlığı Ortaöğretim Yönetmeliği 4. Maddesinde belirtilen 40 dakikalık bir ders saati süresi dikkate alındığında 256 dakikaya karşılık gelmektedir.

Öğrenme miktarı ve hesaplanan parametre değerleri arasındaki bağıntı incelendiğinde; $\mathrm{K} 1$ öğrencisi tam öğrenme alt sınır seviyesine 1.8, K58 öğrencisi 2.49 ve K148 öğrencisi ise 11.17 ders saatinde ulaşmıştır. Öğrencilerin ders sürelerindeki bu değişime gerekçe olarak K1 öğrencisinin kazanımdan elde ettiği 48 puan, K58 öğrencisinin 24 puan, ve K148 öğrencisinin 3 puan alması olarak gösterilebilir. Bu sonuçlardan da anlaşılacağı üzere öğrenme güçlüğünün artışına bağlı olarak tam öğrenme düzeyi için gerekli olan süre miktarında da artış olmaktadır. Tam öğrenmeye en yakın düzey olan 0.999 öğrenme seviyesine öğrenme grubu 6.4, K1 öğrencisi 3.53, K58 öğrencisi 5.81 ve K148 öğrencisi ise 37.70 ders saatinde ulaşabilmektedir. Elde edilen bu sonuçlara göre, öğrenme miktarının artışına bağlı olarak öğrencilerin daha çok öğrenme güçlüğü yaşadığını ve bu değişimin özellikle tam öğrenme düzeyine yaklaşıldıkça belirginleştiği söylenebilir.

Öğrenme grubunun 0.001-0.333 öğrenme miktar aralığındaki öğrenme güçlüğü 0.274 iken bu sonuç K1 öğrencisinde 0.352'yi, K58 öğrencisinde 0.288 'i ve K148 öğrencisinde 0.616'y1 göstermektedir. 0.333-0.666 öğrenme miktar aralığındaki öğrenme güçlüğü hem öğrenme grubunda hem de K1 ve K58 öğrencilerinde 0.416 iken K148 öğrencisinde ise 0.414 olmaktadır. 0.666-0.999 öğrenme miktar aralığını incelediğimizde öğrenme grubunun öğrenme güçlüğü 0.559 , K1 öğrencisinin 0.480 , K58 öğrencisinin 0.543 ve K148 öğrencisinin 1.431 olmaktadır. Eurydice (2011) yayınladığı raporda ilk ve orta eğitimde uygulanan değerlendirme şekilleri ve ölçütleri kadar öğrencilerin matematik öğrendiği süre (ders saati) faktörü de öğrenci başarısına önemli bir katkıda bulunmaktadır. Bu bağlamda, öğrencilerin kesir problemleri ile ilgili kavramların öğrenilmesinde yaşadığı güçlüklerde (Soylu ve Soylu, 2005), kesirlerin pay ve paydalarını ayrı ayrı düşünüp işlem yapmalarında (Biber ve diğerler, 2013), işlemi soru köküne yansıtamamalarında (Işık ve Kar, 2012), paydası eşit olmayan kesirlerde yapılan işlem hatalarında (Altıparmak ve Özüdoğru, 2015) ders saati süresinin etkisi de düşünülmesi gereken bir konu olarak karşımıza çıkmaktadır. Elde edilen bulgular, matematik dersi için önerilen ders saati sürelerinin kazanımlara uygun bir şekilde dağıtılmasının öğrenme hedeflerine ulaşmada önemli bir role sahip olduğunu göstermektedir. Nitekim öğrencilerin matematik başarısını en çok yordayan değişkenin öğrenmeye ayırdıkları zaman değişkeni (Özer ve Anıl, 2011) olduğu düşünüldüğünde, öğrencilerin matematik 
öğrendiği süre (ders saati) faktörü de öğrenci başarısında önemli bir etken olduğu ifade edilebilir. Özellikle öğrenme miktarı ile zaman arasındaki parametre değerleri arasındaki bağıntı bu durumu desteklemektedir.

Sonuç olarak, yürütülen çalışmanın alana sağlayacağı en önemli katkılardan biri de belirli süre dâhilinde öğrenme hedefleri belirleyen tüm eğitim kademeleri ile tüm öğretim programlarında yer alan her bir kazanım için tam öğrenme düzeyine en yakın ders saati sürelerinin belirlenebilmesidir. Çalışma sayesinde tam öğrenme düzeyine ulaşılması için gerekli olan süre sonsuza uzansa bile tam öğrenme düzeyine en yakın miktar göz önüne alındığında ihtiyaç duyulan ders saati süresinin hangi süre bandında yer alabileceği belirlenebilmektedir. Ancak belirtilen durumlar kendi sınırlılıkları içerisinde değerlendirilmelidir. Örneğin yürütülen çalışma altıncı sınıf düzeyinde tek bir kazanıma [kesirlerle işlem yapmayı gerektiren problemleri çözer] yönelik gerçekleştirilmiştir. Daha farklı veya fazla kazanımlarla konunun alanı genişletilebilir. Ayrıca öğretim programında yer alan kazanımlara ait ortalama ders saati süresi dikkate alınmıştır. Bundan dolayı kazanıma ayrılabilecek ders saatinin süresi farklılık gösterilebilir. Fakat bu farklılık çalışmanın ana kurgusunu etkiyebilecek nitelikte değildir. Çünkü kazanım için belirlenen ders saatinin süreleri ne olursa olsun öğrenenin tam öğrenme düzeyine ulaşması için gerekli olan sürenin belirlenmesi rahatlıkla yapılabilir. Bunun yanı sıra çalışmanın alana yapacağı en önemli katkı ise tüm eğitim kademelerinde yapılabilir olmasıdır. Özellikle farklı konu, düzey ve dersler için benzer çalışmalar yapılabileceği gibi farklı kazanımlara uygun farklı yöntemlerle daha derin araştırmalar da yürütülebilir. $\mathrm{Bu}$ sayede tüm öğretim kademelerinin müfredatlarının içeriği hazırlanırken kazanımlara uygun ders saati sürelerinin belirlenmesinde geniş bir örneklem grubu üzerinde çalışmalar yapılarak karar verilebilir.

\section{KAYNAKLAR}

Alkan, C., Deryakulu, D. ve Şimşek, N. (1995). Eğitim teknolojisine giriş. Ankara: Önder Matbaacılık Ltd. Şti.

Alkan, V. (2011). Etkili matematik öğretiminin gerçekleştirilmesindeki engellerden biri: Kaygı ve nedenleri. Pamukkale Üniversitesi Ĕgitim Fakültesi Dergisi, 29(1), 89-107.

Altıparmak, K. ve Özüdoğru, M. (2015). Hata ve kavram yanılgısı: Kesir ve parça bütün ilişkisi. Uluslararası Insan Bilimleri Dergisi, 12(2), 14651483.

Bağcı, O. (2015). Ortaokul matematik 6 ders kitabı. Ankara: Tutku Yayınları.

Bandura, A. (1997). Self-efficacy: The exercise of control. New York: Freeman.

Biber, A. Ç., Tuna, A. ve Aktaş, O. (2013). Students' misconceptions of fractions and its effect on solving fractions problems. Trakya University Journal of Education, 3(2), 152-162.

Brown, G., \& Quinn, R. (2006). Algebra students' difficulty with fractions: An error analysis. Australian Mathematics Teacher, 62(4), 28-40. 
Charalambous, C. Y., \& Pitta-Pintazi, D. (2005). Revisiting a theoretical model on fractions: implications for teaching and research. In Chick, H. L. \& Vincent, J. L. (Eds.). Proceedings of the $29^{\text {th }}$ Conference of the International Group for the Psychology of Mathematics Education, 2, 233-240.

Çiltaş, A., Güler, G. ve Sözbilir, M. (2012). Türkiye'de matematik eğitimi araştırmaları: Bir içerik analizi çalışması. Kuram ve Uygulamada Eğitim Bilimleri, 12(1), 565-580.

Ersoy, Y. (2005). Movements for innovations of mathematics education-I: Technology supported mathematics teaching. The Turkish Online Journal of Educational Technology, 4(2), 51-63.

Eurydice (2011). Mathematics education in Europe: Common challenges and national policies. http://eacea.-ec.europa.eu/ (Erişim Tarihi: 3 Mart 2016).

Fujimura, N. (2001). Facilitating children's proportional reasoning: A model of reasoning processes and effects of invervetion on strategy change. Journal of Educational Psychology, 93(3), 589-603.

Haser, Ç. ve Ubuz, B. (2002). Conceptual and procedural performance in fractions. Education and Science, 27(126), 53-61.

Heppner, P. P., \& Lee, D. (2009). Problem-solving appraisal and psychological adjustment. Oxford Handbook of Positive Psychology. Edited by C. R. Snyder \& Shane L. Lopez. Oxford Library of Psychology.

Işık, C. ve Kar, T. (2012). 7. sınıf öğrencilerinin kesirlerde toplama işlemine kurdukları problemlerin analizi. Ilköğretim Online, 11(4), 1021-1035.

Karasar, N. (2009). Bilimsel araştırma yöntemi (20. Bask1). Ankara: Nobel Yayın Dağıtım.

Kardash, C. M., \& Howell, K. L. (2000). Effects of epistemological beliefs and topic-specific beliefs on undergraduates' cognitive and strategic of dualpositional text. Journal of Educational Psychology, 92(3), 524-35.

Kayhan, A. ve Özgün-Koca, S. A. (2004). Matematik eğitiminde araştırma konular1: 2000-2002. Hacettepe Üniversitesi Ĕ̈itim Fakültesi Dergisi, 26, $72-81$.

Kocaoğlu, T. ve Yenilmez, K. (2010). Beşinci sınıf öğrencilerinin kesir problemlerinde yaptıkları hatalar ve kavram yanılgıları. Dicle Üniversitesi Ziya Gökalp Eğitim Fakültesi Dergisi, 14, 71-85.

Küçük, A. ve Demir, B. (2009). İlköğretim 6-8. sınıflarda matematik öğretiminde karşılaşılan bazı kavram yanılgıları üzerine bir çalışma. Dicle Üniversitesi Ziya Gökalp Ĕgitim Fakültesi Dergisi, 13, 97-112.

Marzano, R. J. (2000). Transforming classroom grading. Alexandria, VA: Association for Supervision and Curriculum Development.

Meece, J. (1996). Gender differences in mathematics achievement: The role of motivation. M. Carr (Ed.), Motivation in mathematics. New Jersey: Hampton Press. 
Milli Eğitim Bakanlığı (MEB) (2013). Ortaokul matematik dersi (5, 6, 7 ve 8. sınıflar) öğretim programı. Ankara: Talim Terbiye Kurulu Başkanlığı.

Misquitta, R. (2011). A review of the literature: Fraction instruction for struggling learners in mathematics. Learning Disabilities Research \& Practice, 26(2), 109-119.

Nagle, R. K., Saff, E. B., \& Snider, A. D. (2013). Diferansiyel denklemlerin temelleri (O. Doğru, Çev.) Ankara: Nobel Akademik Yayıncılık.

Özer, Y., \& Anıl, D. (2011). Öğrencilerin fen ve matematik başarılarını etkileyen faktörlerin yapısal eşitlik modeli ile incelenmesi. Hacettepe Üniversitesi Eğitim Fakültesi Dergisi, 41, 313-324.

Pesen, C. (2008). Kesirlerin sayı doğrusu üzerindeki gösteriminde öğrencilerin öğrenme güçlükleri ve kavram yalgıları. Inönü Üniversitesi Eğitim Fakültesi Dergisi, 9(15), 157-168.

Rasmussen, C. L. (1998). Reform in differential equations: A case study of students' understandings and difficulties. Unpublished doctoral dissertation, Purdue University, Calumet. https:/files.eric.ed.gov/fulltext/ED420508.pdf (Erişim Tarihi: 22 Ocak 2016).

Resmi Gazete (2014). T. C. Resmi Gazete, 13 Eylül, (29118). http://www.resmigazete.gov.tr-/default.asp (Erişim Tarihi: 6 Ocak 2016).

Scott, P. H., Asoko, H. M., \& Driver, R. H. (1991). Teaching for conceptual change: A review of strategies. Connecting research in physics education with teacher education, 71-78. http://www.univie.ac.at/pluslucis/Archiv/ICPE/C5.html (Erişim Tarihi: 26 Ocak 2016).

Soylu, Y. ve Soylu, C. (2005). İlköğretim beşinci sınıf öğrencilerinin kesirler konusundaki öğrenme güçlükleri: Sıralama, toplama, çıkarma, çarpma ve kesirler ile ilgili problemler. Erzincan Eğitim Fakültesi Dergisi, 7(2), 101-118.

Steffe, L. P., \& Olive, J. (2010). Children's fractional knowledge. New York: Springer.

Tall, D. O., \& Razali, M. R. (1993). Diagnosing students' difficulties in learning mathematics. International Journal of Mathematical Education in Science and Technology, 24(2), 209-222.

Tatar, E. ve Dikici, R. (2008). Matematik eğitiminde öğrenme güçlükleri. Mustafa Kemal Üniversitesi Sosyal Bilimler Enstitüsü Dergisi, 5(9), 183193.

Toluk-Uçar, Z., Pişkin, M., Akkaş, E. N., \& Taşçı, D. (2010). İlköğretim öğrencilerinin matematik, matematik öğretmenleri ve matematikçiler hakkındaki inançları. Eğitim ve Bilim, 35(155), 131-144.

Yağbasan, R. ve Gülçiçek, Ç. (2003). Fen öğretiminde kavram yanılgılarının karakteristiklerinin tanımlanması. Pamukkale Üniversitesi Eğitim Fakültesi Dergisi, 13(1), 102-120. 


\section{EXTENDED ABSTRACT}

In general, the studies which examine learning process, especially human learning process, have been presented with effective results. Spend time depending the quality of learning may be mostly significant for people who use information, which is one of the most important inputs of learning process. The effective use of learning course time in achieving the learning goals has come to the fore. The proposed lesson time particularly for the mathematics class in primary and secondary schools (the curriculum time that mathematics is taught), as well as being a very important quality that helps explain the importance of a subject when compared with other, is closely related to degree of difficulty of the subject taught or the comprehension level of the learner. In spite of the fact that the concept of learning has not been characterized a case that belongs a significant period and results in a significant time, it has been realized that some children learn more easily and frequently with regarding to their levels of development and learning. In this situation, it can be mentioned that there might be some elements, which affect learning process, such that are learner, learned thing, instructive person, learning and learning environment. It can be also searched traces of a theoretical understanding in order to find the answer of "What is the impact of the alloted time on learning?". Because the concept of learning forms a product (learned thing) or processes of delivering the product. Nevertheless, it should be significant enough to be remembered, consistent enough to be understood and pleasant enough to be permanent.

The average course period allocated to the gain of " solving problems that require calculating of swith fractions ", which is included in the sixth grade mathematics curriculum in our country corresponds to 2.66 hours. What is the relationship between the course periods set for this and this kind of gains and students' amount of learning? What level of learning do the learning groups or the learners reach in a specified course period? Moving from the above questions; the purpose of this study is to determine the amount of timedependent learning of " solving problems that require calculating of swith fractions " of the sixth grade students. Also, one of the most important reasons for the study conducted is to create a structure that will reveal the quantitative relation between time and learning. In a study conducted at the sixth grade level, "solving problems that require calculating of swith fractions" was discussed. Although a particular preference is not made while selecting topics, both the fact that it is a challenging topic for students and that the students have learned the related topic before the study have been taken into account.

The general and individual screening models were used in the study. The study group consists of a total of 148, 6th grade students, including 80 girls $(54.1 \%)$ and 68 boys $(45.9 \%)$, who attend a public secondary school in the province of İzmir, during the 2015-2016 academic year. In the study, the "fractions" asked after the learning area was taught. The procedures to be performed on the study group are as follows: 
$\checkmark$ Determination of time-dependent learning amount of the learning group, $\checkmark$ Determination of time-dependent learning amount of the K1, K58 and K148 students.

The data collection tool consists of the literature, teachers and the problems including the unit of fractions prepared based on the secondary school sixth-grade math textbook. Firstly, candidate problems were prepared in accordance with the objective, content and analysis of the measuring tool by a group of experts, and then whether the problems created represented these objectives and content was discussed. After the necessary studies were conducted, the essential corrections and adjustments were made in line with the recommendations of three math teachers and three field trainers. Thus, the language, content, relevance and scope of validity of the question were provided. By applying the questions belonging to the first form, which took their final shape, to 15 students, the pilot study was conducted. Thanks to the pilot study, the points that students had difficulty understanding were identified and the necessary corrections were made. In order to test the construct validity of the 12item data collection tool developed, the Confirmatory Factor Analysis (CFA) was performed $\left[\mathrm{x}^{2}=113.736 ; \mathrm{p}<0.01 ; \mathrm{x}^{2} / \mathrm{sd}=2.14 ; \mathrm{CFI}=0.96 ; \mathrm{RMSEA}=0.08\right.$; $\mathrm{IFI}=0.96 ; \mathrm{GFI}=0.89 ; \mathrm{AGFI}=0.84 ; \mathrm{NFI}=0.93]$. The Cronbach Alpha reliability coefficient of the final 12-item measuring tool was calculated as $0.95(n=160)$. The questions prepared in order to determine the quality of learning were prepared to reveal the characteristic feature of the related gain, and following the necessary corrections, the measurement tool became ready for application. The maximum score that can be taken from the measuring tool was set as 48 and the minimum score as 0 .

SPSS 20.00 and IBM AMOS software packages were used in the development of the measurement tool, and Graph software was used in drawing the graphs. The progressive scores scale which was developed by Marzano (2000), to analyze the 12 open-ended questions, which cover the acquisition of "solving problems that require calculating of swith fractions" of the first order that belongs to the learning area of numbers and operations and the lower learning area of operations with fractions are in the Curriculum of Secondary School Mathematics Course was used. If student chooses the most effective way to overcome a difficult situation and if the student can explain why this way might be the most effective one, 4 points are given to the student. If student chooses the most effective way to overcome a difficult situation but the student cannot explain why this way might be the most effective one, 3 points are given to the student. If student chooses a right way to overcome a difficult situation but this way is not the most effective one and if the student gives an answer partially, 2 points are given to the student. If student chooses a way but it is not sufficient to overcome the difficult situation, 1 point is given to the student. If student does not make any judgment, 0 point is given to the student. To determine the amount of time-dependent learning the formula that specifies the model of learning a task in psychology was utilized (Nagle, Saff and Sinder, 2013): 
$\checkmark \mathrm{n}=$ the qualification of the learning [the number of questions that characterize the subject learned]

$\checkmark \mathrm{p}=$ the qualification of the person/group [acquisition/success derived from the acquisitions]

$\checkmark \mathrm{c}=$ the arbitrary constant which depending on personal learning

$\checkmark \mathrm{y}=$ the amount of learning

$\checkmark \mathrm{t}=$ time [learning time of the acquisition]

A total of 148 students whom we described as the learning group reached the learning amount of 0.987 in a period of 2.66 course hours for this acquisition. The obtained amount was determined as the lower limit of the learning amount for the learning group, K1, K58 and K148 in order to make the results more understandable. In this context, the data obtained from the learning group show that the students fell 0.013 points behind the complete learning level. Despite this small deviation in the learning amount, a period of 6.4 course hours is needed for the closest value to the complete learning level. This time period corresponds to 256 minutes considering the course time of 40 minutes which is specified in article 4 of the Ministry of Education Secondary Education Regulations published on the Official Gazette dated 2014 and issued 29118. Besides this, it has been concluded that the increase in the time of course hours also increase due to a small increase in the amount of learning, as students come closer to the complete learning level. Considering the relationship between the amount of learning and parameter values; K1 student reach the lower limit of complete learning in 1.8 course hours, K58 student 2.49 course hours while K148 student reach this limit in 11.17 course hours. The reason for the change in the times of K1, K58 and K148 can be due to the fact that the average point that the $\mathrm{K} 1$ student obtained from the acquisition was 48 , K58 student 24 while this average was 3 points in K148. As can be understood from these results; depending on the increase in the quality of learning, an increase occurs in the time needed for complete learning. The learning amount of 0.999 , which is the closest value to the complete learning level, was reached by the learning group in a period of 6.4 course hours, by the K1 student in 3.53 course hours, by the K58 student in 5.81 and by the K148 student in 37.70 course hours. Therefore, as there was a decrease in learning level, there was an increase in time period that was necessary to reach the full learning level. In the light of the data obtained, when the amount of learning is fixed and the allotted time for learning decreases, we can say that students experience fewer learning difficulties. Thanks to the study conducted, even though the time required for complete learning extends to infinity; considering the closest amount to the complete learning level, it is possible to determine what time range the course hours needed may be located in. As a result, the most important contribution of this study to the literature is the fact that the closest periods of course hours to the complete learning level can be determined for each acquisition included in all level of education which determine learning objectives within a certain period and in all educational programs. 